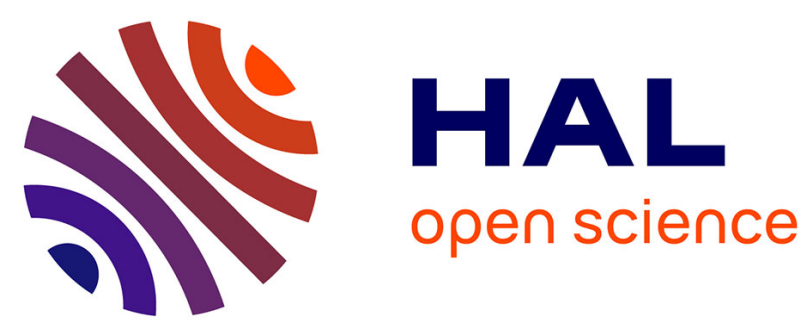

\title{
Mapping soil multifunctionality for urban planning: how to deal with limited knowledge on soils?
}

\author{
C. Le Guern, T Leroi, B. Béchet, Christophe Ducommun, Joël Moulin, B. \\ Laroche, C Duvigneau, C. Keller, C. Neel, F Marseille, et al.
}

\section{To cite this version:}

C. Le Guern, T Leroi, B. Béchet, Christophe Ducommun, Joël Moulin, et al.. Mapping soil multifunctionality for urban planning: how to deal with limited knowledge on soils?. EGU 2020 - Online, May 2020, Vienne - Online, Austria. 10.5194/egusphere-egu2020-11491 . hal-02481191

\section{HAL Id: hal-02481191 https: / hal-brgm.archives-ouvertes.fr/hal-02481191}

Submitted on 17 Feb 2020

HAL is a multi-disciplinary open access archive for the deposit and dissemination of scientific research documents, whether they are published or not. The documents may come from teaching and research institutions in France or abroad, or from public or private research centers.
L'archive ouverte pluridisciplinaire HAL, est destinée au dépôt et à la diffusion de documents scientifiques de niveau recherche, publiés ou non, émanant des établissements d'enseignement et de recherche français ou étrangers, des laboratoires publics ou privés. 
Mapping soil multifunctionality for urban planning: how to deal with limited knowledge on soils?

C. Le Guern ${ }^{1,4 *}$, T. Leroi ${ }^{1,4}$, B. Béchet ${ }^{2,4}$, C. Ducommun ${ }^{3,4}$, J.Moulin $^{5}$, B. Laroche ${ }^{6}$, C. Duvigneau ${ }^{4}$, C. Keller $^{7}$, C. Néel ${ }^{8}$, F. Marseille ${ }^{9}$, P. Branchu ${ }^{10}$

${ }^{1}$ BRGM, Nantes, France

${ }^{2}$ GERS-LEE, Univ Gustave Eiffel, IFSTTAR, F-44344 Bouguenais, France

${ }^{3}$ AGROCAMPUS OUEST, EPHOR, 49045 Angers, France

${ }^{4}$ IRSTV - FR CNRS 2488, 44321 Nantes, France

${ }^{5}$ Chambre d'Agriculture de l'Indre, 36000 CHATEAUROUX France

${ }^{6}$ INRAE, US 1106 INFOSOL Unité INFOSOL. Centre de recherche Val de Loire, 45075 ORLEANS, France

${ }^{7}$ Aix Marseille Univ, CNRS, IRD, INRAE, Coll France, CEREGE, Aix-en-Provence, France

${ }^{8,9,10}$ CEREMA, France

Urban planning historically considers soils as a support for infrastructures. Hopefully, awareness is increasing on the fact that soils offer many more services than just this one, thanks to their various functions. It is therefore necessary to develop methodologies and tools that allow the urban planners to take into account the opportunities and constraints associated to soils. Considering the existing quality indexes already developed by the researchers, we faced within the MUSE project various difficulties and in particular the lack of knowledge on urban soils in France. We therefore developed a methodology to deal with limited knowledge on urban soils and tested it first on the Nantes metropolis territory (France). Our aim was to map each soil function as well as a soil multifunctionality in such a way that urban planning documents may refer to them.

The aim of the multifunction map is to help protecting soils that show various functions, including patrimonial functions. We therefore considered the following functions: carbon storage, water storage and infiltration, storage and filtration of contaminants, agronomic potential, biodiversity reservoir. We did not consider the support and natural resources provision functions. According to the level of knowledge on soils (local/regional/national scales, direct/indirect), we considered three mapping approaches (statistical, global, and calculation) to build function maps, and interpreted them in terms of soil function index (SFI) map. To build the soil multifunctionality quality index (SMQI) map, we crossed the various function index maps using a ponderation according to the territorial issues. These issues derive from discussions with the urban planners of the local authority and the number of functions assessed on each part of the territory (some functions not mapped in the city center). We carried out discussions with the urban planners all along the methodological development process to ensure applicability of the index map produced.

The results obtained are very satisfying considering the level of knowledge on soils. The urban planners of the local authority clearly imagine how to use both the soil function maps as well as the soil multifunctionality quality index map. We are nevertheless aware of the limits due to the use of data with different scales of validity (eg. 1 / 250000 for pedological map; 1/10 000 for soil land-use model; statistical data on $\mathrm{C}$ and biodiversity at pedoclimatic scale vs national scale). The comparison with local punctual data helps verifying the degree of confidence of the maps. The methodological development is currently being adjusted and tested on other cities (in particular Marseilles and Châteauroux, France) and further discussed with urban planners at national scale. Efforts are necessary to build a wider and 
more precise knowledge on urban soils by gathering and sharing existing data. This implies building reference knowledge and by defining the most useful properties to acquire in a systematic way to characterize soils so as to optimise urban planning and development. 